\title{
Management Guidelines for Metal-on-metal Hip Resurfacing Arthroplasty: A Strategy on Followup
}

\begin{abstract}
Despite the initial promise of metal-on-metal (MoM) implants as the ideal bearing surface for hip replacements and resurfacings, high short term failure rates due to an adverse reaction to metal debris (ARMD) have led to a dramatic reduction in the number of MoM implants used in the modern era. With over one million patients worldwide having undergone hip operations utilizing a MoM bearing surface, the long term outcomes for such patients remains unknown, and there is much debate as to the most effective management of these patients. Although several regulatory bodies have released guidelines on the management of patients with MoM hips, these recommendations remain open to interpretation, and the most effective management for these patients remains unclear. The aim of this review is to compare the current guidelines for managing patients with MoM hips and also to discuss established ARMD risk factors, evidence regarding the optimum management for patients with MoM hips, and the indications for revision surgery. Furthermore, although specialized laboratory tests and imaging can be used to facilitate clinical decision making, over-reliance on any single tool should be avoided in the decision making process, and surgeons should carefully consider all findings when determining the most appropriate course of action.
\end{abstract}

Keywords: Adverse reaction to metal debris, follow up, guideline, hip replacement, hip resurfacing, metal-on-metal, patient management

MeSH terms: Replacement, arthroplasty, hip, reoperation, prosthesis

\section{Introduction}

The increasing incidence of polyethylene associated complications in Metal-on-Polyethylene (MOP) bearings in the early 2000s led to a resurgence of the metal-on-metal (MoM) bearing in total hip arthroplasty (THA) surgery. ${ }^{1}$ Initial promise from MoM THAs was rooted in a proposed reduction in failure rates due to diminished volumetric wear, greater component stability, and avoidance of polyethylene wear-induced osteolysis., ${ }^{2,3}$ Parallel to this, MoM bearing was found to have a number of unique advantages in hip resurfacing. These included the ability to preserve bone stock in the younger patients, low dislocation rates, improved proprioception and gait, and the perceived ease of future conversion to a THA. ${ }^{4}$ In addition, it has been suggested that it is safe to return to high impact activity following hip resurfacing - something highly valuable to younger individuals undergoing hip resurfacing procedures. ${ }^{5}$

Despite these initial benefits, high short term failure rates due to adverse reaction

This is an open access article distributed under the terms of the Creative Commons Attribution-NonCommercial-ShareAlike 3.0 License, which allows others to remix, tweak, and build upon the work non-commercially, as long as the author is credited and the new creations are licensed under the identical terms.

For reprints contact: reprints@medknow.com to metal debris (ARMD) in MoM bearings have been reported, leading to concerns over their use. ${ }^{6-11}$ ARMD is the sequelae of metal debris released from MoM bearings due to wear and corrosion. ${ }^{12}$ This process results in destructive soft-tissue masses adjacent to the bearing and often necessitates surgical revision. As such, ARMD lesions have been branded "inflammatory pseudotumor." ${ }^{13}$ Although the size of particulate matter generated by a MoM bearing is significantly smaller than that of a MoP bearing, these adverse inflammatory effects are theorized to be the result of a greater volume of particle generation and these particles being much more biologically active. ${ }^{14}$ In addition, the significant bone loss and muscle damage that results from ARMD means that short-term outcomes following revision surgery are often poor. ${ }^{15,16}$ These poor outcomes have attracted particular attention as most patients who received MoM bearings are young and active. ${ }^{17-19}$

The poor outcomes associated with MoM bearings, and the subsequent recall of specific implants has led to a

How to cite this article: Nakano N, Volpin A, Bartlett J, Khanduja V. Management guidelines for metal-on-metal hip resurfacing arthroplasty: A strategy on followup. Indian J Orthop 2017;51:414-20.

\section{Naoki Nakano, Andrea Volpin, Jonathan Bartlett, Vikas Khanduja}

Department of Trauma and Orthopaedics, Addenbrooke's Hospital, Cambridge University Hospitals NHS Foundation Trust, Cambridge, CB2 OQQ, $U K$

\section{Address for correspondence: Mr. Vikas Khanduja, Consultant Orthopaedic Surgeon and Elective Clinical Trials Research Lead, Department of Trauma and Orthopaedics, Cambridge University Hospitals NHS Foundation Trust, Box 37, Hills Road, Cambridge, \\ CB2 OQQ, UK. \\ E-mail:vk279@cam.ac.uk}

\section{Access this article online}

Website: www.ijoonline.com DOI:

10.4103/ortho.IJOrtho_230_17

Quick Response Code:

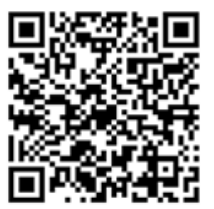


dramatic reduction in the number of MoM THA and hip resurfacing procedures performed today. However, as over a million patients worldwide have already been implanted with MoM devices, a clear management strategy for patients with MoM hips is essential. ${ }^{20}$ Regulatory authorities have published guidance on the regular followup and management of patients with MoM hips. $^{21-26}$

\section{Metal-on-metal management guidelines}

Management guidelines for MoM hips have been published by five authorities in various countries and regions. These include:

1. United States of America Food and Drug Administration (FDA) ${ }^{21}$

2. United Kingdom Medical and Healthcare Products Regulatory Agency (MHRA) ${ }^{22}$

3. European Federation of National Associations of Orthopaedics and Traumatology (EFORT) ${ }^{23}$

4. Health Canada ${ }^{26}$

5. Therapeutic Goods Administration of Australia (TGA). ${ }^{25}$

Surveillance strategy guidance

Each authority provides guidance on the patient selection for followup, and the frequency at which this should occur [Table 1].

Symptomatic and asymptomatic metal-on-metal hip investigations and imaging

Each of the five authorities also provide guidance regarding the investigations and imaging patients with MoM hips should receive [Table 2], and further discusses which metal ions should be sampled and the acceptable values for each [Table 3].

Which patients are at risk of adverse reaction to metal debris?

Patients can be stratified into high- and low-risk groups depending on implant specific and patient specific factors. Implant specific factors that increase the risk of ARMD are THAs with large diameter femoral head components or the DePuy ASR implants. In addition, several implant specific factors correlate with a lower risk of ARMD, including THAs with small diameter femoral head components, and hip resurfacing implants. ${ }^{22}$ Several studies have described patient factors associated with increased failure rates in MoM hips. In a systematic review, an increased risk of developing ARMD, and higher rates of dislocation, aseptic loosening and revision after MoM hip resurfacings were found in female patients. ${ }^{27}$ Although the reasons for this finding are unclear, it has been theorized that the higher prevalence of developmental dysplasia in females may affect the accuracy of acetabular component positioning, resulting in higher rates of impingement, edge loading, and wear. ${ }^{28}$ In addition, metal hypersensitivity has been reported as an important factor in the pathology of ARMD following histological examination of peri prosthetic tissue. ${ }^{29,30}$ Another theorized risk factor for ARMD is that of low body mass index (BMI). A recent study demonstrated a negative correlation between BMI and elevated $\mathrm{Cr}$ level. ${ }^{28}$ Although the authors suggested that differences in activity level could explain this relationship, further studies

\begin{tabular}{|c|c|c|c|}
\hline Authority & $\begin{array}{l}\text { Recommended followup schedule } \\
\text { for asymptomatic patients }\end{array}$ & $\begin{array}{l}\text { Recommended followup schedule } \\
\text { for symptomatic patients }\end{array}$ & Additional guidance \\
\hline $\mathrm{FDA}^{*}$ & Every $1-2$ years & Every 6 months & $\begin{array}{l}\text { Closer followup should be considered for those } \\
\text { with increased risk factors of increased device } \\
\text { wear. These include female, those who received hip } \\
\text { resurfacing with a small femoral head component } \\
(\leq 44 \mathrm{~mm}) \text {, those with bilateral hip implants, and } \\
\text { those with suboptimal component alignment }\end{array}$ \\
\hline MHRA & $\begin{array}{l}\text { Annual followup for THA cases with } \\
\text { large femoral head component }(\geq 36 \\
\mathrm{mm})\end{array}$ & $\begin{array}{l}\text { Annual followup for hip } \\
\text { resurfacing cases }\end{array}$ & $\begin{array}{l}\text { No guidelines are given for patients that do not } \\
\text { meet these criteria }\end{array}$ \\
\hline EFORT & $\begin{array}{l}\text { Annual followup for THA cases with } \\
\text { a large femoral head component }(\geq 36 \\
\text { mm) and hip resurfacing cases with } \\
\text { defined risk factors for ARMD }\end{array}$ & No specific guidelines provided & $\begin{array}{l}\text { Defined risk factors are described as female gender, } \\
\text { low coverage arc, and small femoral head size }\end{array}$ \\
\hline $\begin{array}{l}\text { Health } \\
\text { Canada* }\end{array}$ & $\begin{array}{l}\text { Annual followup for first } 5 \text { years for } \\
\text { asymptomatic patients with MoM hips }\end{array}$ & No specific guidelines provided & $\mathrm{N} / \mathrm{A}$ \\
\hline TGA & $\begin{array}{l}\text { Annual follow-up for cases with } \\
\text { large }(\geq 45) \text { or small }(\leq 36) \text { femoral } \\
\text { head components }\end{array}$ & $\begin{array}{l}\text { TGA Australia recommends annual } \\
\text { followup for symptomatic patients } \\
\text { with MoM hip cases }\end{array}$ & $\begin{array}{l}\text { No guidelines given for patients other than those } \\
\text { described }\end{array}$ \\
\hline
\end{tabular}

*Unlike other authorities, the FDA and Health Canada make no distinction between the followup of hip replacement and hip resurfacing. FDA=Food and Drug Administration, MHRA=Medical and Healthcare Products Regulatory Agency, EFFORT=European Federation of National Associations of Orthopedics and Traumatology, TGA=Therapeutic Goods Administration, THA=Total hip arthroplasty, $\mathrm{ARMD}=\mathrm{Adverse}$ reaction to metal debris, $\mathrm{MoM}=\mathrm{Metal}-\mathrm{on}-\mathrm{metal}, \mathrm{N} / \mathrm{A}=\mathrm{Not}$ available 


\begin{tabular}{|c|c|c|}
\hline Authority & $\begin{array}{l}\text { Guidance regarding investigation and imaging of } \\
\text { asymptomatic MoM hips }\end{array}$ & $\begin{array}{l}\text { Guidance regarding investigation and } \\
\text { imaging of symptomatic MoM hips }\end{array}$ \\
\hline$\overline{\text { FDA }}$ & No guidance provided & $\begin{array}{l}\text { Radiograph of hips, imaging (MARS MRI, } \\
\text { CT or ultrasound) and metal ion sampling }\end{array}$ \\
\hline MHRA & $\begin{array}{l}\text { Metal ion sampling for asymptomatic THA cases, and imaging } \\
\text { is recommended if blood metal ion levels rise }\end{array}$ & $\begin{array}{l}\text { Metal ion sampling and imaging (MARS } \\
\text { MRI or ultrasound) }\end{array}$ \\
\hline EFORT & $\begin{array}{l}\text { Radiographs and metal ion sampling for all asymptomatic hips. } \\
\text { Further imaging for asymptomatic hips with an abnormality in } \\
\text { radiographs, or with Co concentrations between } 2-7 \mu \mathrm{g} / \mathrm{L}\end{array}$ & $\begin{array}{l}\text { Radiograph of hips, imaging (MARS MRI, } \\
\text { CT or ultrasound) and metal ion sampling }\end{array}$ \\
\hline $\begin{array}{l}\text { Health } \\
\text { Canada }\end{array}$ & No guidance provided & $\begin{array}{l}\text { Radiographs, imaging (MARS MRI or } \\
\text { ultrasound) and metal ion sampling }\end{array}$ \\
\hline TGA & $\begin{array}{l}\text { Radiographs, imaging and metal ion sampling for cases with } \\
\text { femoral heads } \leq 36 \mathrm{~mm} \text { or } \geq 45 \mathrm{~mm}\end{array}$ & $\begin{array}{l}\text { Radiographs, imaging (MARS MRI or } \\
\text { ultrasound) and metal ion sampling }\end{array}$ \\
\hline
\end{tabular}

Table 3: Metal ion sampling recommendations and advised thresholds by authorities

\begin{tabular}{lll}
\hline Authority & Metal ion sampling recommendations & Thresholds advised \\
\hline FDA & Sampling of whole blood cobalt and chromium & Not provided \\
MHRA & Sampling of whole blood cobalt and chromium & Concentrations above $7 \mu \mathrm{g} / \mathrm{L}$ should be a cause for concern \\
EFORT & Sampling of whole blood cobalt only & $\begin{array}{l}\text { Asymptomatic patients with concentrations between } 2 \mu \mathrm{g} / \mathrm{L} \\
\text { and } 7 \mu \mathrm{g} / \mathrm{l} \text { require cross-sectional imaging }\end{array}$ \\
& & Concentrations above $7 \mu \mathrm{g} / \mathrm{L}$ should be a cause for concern \\
Health Canada & Sampling of whole blood and serum cobalt and chromium & Not provided \\
\hline
\end{tabular}

FDA=Food and Drug Administration, MHRA=Medical and Healthcare Products Regulatory Agency, EFFORT=European Federation of

National Associations of Orthopaedics and Traumatology, TGA=Therapeutic Goods Administration

assessing activity level in isolation have shown this not to be the case. ${ }^{31}$

\section{What is the evidence base for the frequency of followup?}

As asymptomatic ARMD lesions have been observed in up to $61 \%$ of MoM hips, followup strategies according to symptoms will result in undetected ARMD in a large number of patients. ${ }^{32-34}$ This necessitates regular investigations to identify asymptomatic ARMD.

The necessity of blood metal ion concentration testing has been repeatedly demonstrated, with higher complication rates shown in patients with elevated blood metal ion concentrations. . $^{735-37}$ However, the optimum frequency of these blood test remains unclear. One study found that blood metal ion levels in patients with MoM THAs increased significantly over an 8-month period and that similar increases were not shown in patients who received hip resurfacing. ${ }^{38}$ This led the researchers to suggest that annual blood metal ion measurements are of values in THA followup but not in hip resurfacing. An additional study found that repeating blood metal ion measurements at a mean postoperative time of 27 months in MoM hip resurfacing cases showed no significant increases in Co when compared to the concentration after surgery. ${ }^{36}$ Although these findings highlight the ambiguity with regards to optimum followup frequency, elevated blood levels require further investigation. One study has suggested that if metal ion levels are elevated, radiographs should be evaluated for osteolysis and inappropriate component position. If either is found, then revision surgery should be considered. ${ }^{39}$

In addition to the unclear evidence regarding metal ion blood tests, the benefits of short-term imaging are also questionable. Two previous studies have suggested that patients with normal initial imaging do not need repeat imaging in the short-term, as no significant change was found when repeat imaging was performed at various time intervals..$^{40,41}$ However, the usefulness of magnetic resonance imaging (MRI) scans in surgical decision making decreases drastically if not regularly updated. One study demonstrated that MRI scans performed over 12 months previously had a sensitivity of $29 \%$. This was compared to a sensitivity of $88 \%$ for scans that were 3 -month-old. ${ }^{42}$ From these results, it was suggested that repeat imaging should be performed at least annually, and the usefulness of results over a year old severely questioned. Furthermore, as cyst progression has not been observed earlier than 6 months postoperatively, annual followup has been recommended in other studies. ${ }^{43}$ In addition, although some work has begun to assess the time-course of growth of the pseudotumors, there is a large discrepancy between results. Growth of pseudotumors, remission of small masses, and static pseudotumors have all been documented, highlighting the need for a greater 
understanding of ARMD pathology if we are to establish effective monitoring protocols. . $^{41,44}$

\section{Thresholds for concern with metal ion levels}

Metal ion levels have been extensively used as a surrogate marker for patients with MoM bearings related wear. ${ }^{45}$ The population background level of $\mathrm{Co}$ in blood has been shown to be $0.5 \mu \mathrm{g} / \mathrm{L}$, and the mean Co blood levels in patients with well functioning MoM hip implants ranges between 0.2 and $4 \mu \mathrm{g} / \mathrm{L} .{ }^{46}$ There is correlation seen with wear rates of the MoM joint, where blood levels of $2 \mu \mathrm{g} / \mathrm{L}$ can be expected with wear rates of $2 \mathrm{~mm}^{3}$ / years. ${ }^{37,47}$ In addition, $\mathrm{Co}$ and $\mathrm{Cr}$ ion levels are influenced by the type of MoM implant, head size, implant design, and component positioning. ${ }^{48,49}$ Although one study has shown that $\mathrm{Co}$ is more reliable than $\mathrm{Cr}$, and that whole blood testing is quicker and more accurate than serum, either whole blood or serum, and $\mathrm{Co}$ or $\mathrm{Cr}$, can be used for monitoring as long as the testing modality is consistent. $^{46,50}$ Furthermore, there should be standardized protocols in place for the collection of serum or blood samples, as needle type and collection techniques can influence reported ion concentrations. ${ }^{25,26}$

A retrospective study evaluating the use of $\mathrm{Co}$ and $\mathrm{Cr}$ blood sampling established that cut-off value of $7 \mu \mathrm{g} / \mathrm{L}$ had a specificity of $89 \%$ and a sensitivity of $52 \%$ in detecting failed MoM articulations in patients with normal imaging results, and has been extensively adopted. ${ }^{51}$ Similarly, Hart et al. demonstrated 93\% specificity with a threshold set at $7 \mu \mathrm{g} / \mathrm{L} .{ }^{37}$ Although no single metal ion threshold will reliably identify all ARMD patients, EFORT suggests that $7 \mu \mathrm{g} / \mathrm{L}$ may be too high a threshold, instead recommending a threshold of between $2 \mu \mathrm{g} / \mathrm{L}$ and $7 \mu \mathrm{g} / \mathrm{L}$, with the exact level still to be determined. In addition, the interpretation of metal ion levels can be difficult in patients with a systemic renal disease or additional metallic implants, such as in patients with bilateral MoM implants. Therefore, metal ions levels should be used to guide and should not be used in isolation to determine the need for revision surgery. ${ }^{36,52}$ Surgeons must carefully consider findings from clinical examination, blood test results, and radiologic investigations when determining the likelihood of a failing MoM THA or hip resurfacing.

\section{The essence of clinical examination}

Physical examination is essential in the assessment of painful hips in patients with MoM implants. Patients with ARMD commonly present with early recurrence of preoperative symptoms, or with persistent pain. In addition, radiation of pain to the greater trochanter and down the thigh is a common feature and can result in patients displaying an antalgic gait. ${ }^{53}$ Patients may also present with a palpable mass or fluid collection near the hip. ${ }^{54}$ Over time, this may progress to instability, with or without dislocation, and patients may complain of a "clicking" or "clunking" sensation in the hip. Patients may also experience other symptoms, such as stiffness or reduced range of movement often most evident in the abduction. It is, therefore, imperative to assess the active and passive range of motion of the hip joint. Reproduction of pain on passive extension and active flexion may indicate concomitant iliopsoas tendinopathy. Abductor weakness may indicate peri-prosthetic soft-tissue involvement and is occasionally accompanied by a rash indicating a reaction to the metal ions. ${ }^{55}$

It is vital to obtain a complete history, perform a thorough clinical examination, and conduct relevant investigations to exclude other potential diagnoses. As joint sepsis must be suspected in patients with a history of complicated wound healing, physical examination of the skin should be performed, looking for signs of infection and previous scars. A comprehensive spine and neurovascular examination should also be performed to evaluate possible neurogenic and vascular pain generators. ${ }^{48}$ Due to the destructive nature of ARMD, appropriate assessment in a timely manner is essential. Due to the high rate of asymptomatic pseudotumors, it is also very important for general practitioners to remain vigilant when examining any patient who has previously undergone a MoM THA or a hip resurfacing.

When should revision surgery be considered and conducted?

All the authorities recommend revision surgery in patients with abnormal cross-sectional imaging and/or rising blood metal ions. In addition, the FDA recommends deciding on revision surgery in the context of the overall clinical picture, examination findings and test results, and further suggests early revision surgery in patients with progressive lesions. Both MHRA and EFORT recommend revision surgery if there are abnormal imaging findings and/or if increasing blood metal ion levels are found. EFORT further suggests that a blood Co level above $20 \mu \mathrm{g} / \mathrm{L}$ is an indication for revision. Conversely, Health Canada recommends revision surgery if patients are symptomatic and if a positive MRI appearance (soft tissue mass) is found. They also suggest revision surgery in asymptomatic cases if a soft-tissue mass, or masses, found on MRI are increasing in size. TGA recommends revision surgery if symptoms are persistent with imaging abnormalities and/or increasing of blood metal ions.

Poor short term outcomes have been reported following ARMD revision, with only a few studies assessing prognostic factors of post revision outcome. ${ }^{15,16,18,56,57}$ One study attributed improved outcomes following ARMD revision to early surgery and increased experience. ${ }^{57}$ In the latest internationally recognized guidelines published by Scientific Committee on Emerging and Newly Identified Health Risks (SCENIHR), there was no consensus on the appropriate timing of revision surgery for ARMD in MoM $\mathrm{THA}_{\Lambda}$ or hip resurfacings. ${ }^{24}$ SCENIHR do 
however recommended that revision should be considered when symptoms become persistent, progressive, and unmanageable. Furthermore, they suggest that any patient exhibiting progressive osteolysis, expanding or large pseudotumors, progressive neck thinning or very high metal ion concentrations should also be considered for revision surgery. ${ }^{24}$ Although these recommendations are useful until prognostic factors of adverse outcomes are identified, the need for defined thresholds for revision surgery is paramount. Surgeons should keep in mind that a decision to revise should not be based on a single investigation. Instead, the decision should take the implant type, patient symptoms, imaging findings, metal ion levels, and the activity levels of the patient into account. When revising MoM implants, it is recommended to utilize a non-MoM articulation such as ceramic-on-ceramic or ceramic-on-polyethylene to reduce local metal ion release to decrease the chance of recurrence of ARMD, because poorer outcomes have been reported in patients revised using MoM articulations. ${ }^{58}$

\section{Conclusion}

Patients with MoM bearings should be monitored closely with physical examination, radiographs, metal ion measurement, and imaging. Evidence supporting the management of MoM hips is still lacking in many scenarios, and regulatory guidelines are open to interpretation. When considering revision surgery, no single investigation or aspect of the history should be taken in isolation. Decisions should be aken on a case-by-case basis, with consideration given to all aspects of investigation results and the patient's clinical condition. Until supporting evidence is available, an evidence-based multidisciplinary approach is considered a safe method to help surgeons make decisions and potentially improve patient outcomes.

\section{Financial support and sponsorship}

Nil.

\section{Conflicts of interest}

There are no conflicts of interest.

\section{References}

1. McKee GK, Watson-Farrar J. Replacement of arthritic hips by the McKee-Farrar prosthesis. J Bone Joint Surg Br 1966;48:245-59.

2. MacDonald SJ, McCalden RW, Chess DG, Bourne RB, Rorabeck $\mathrm{CH}$, Cleland $\mathrm{D}$, et al. Metal-on-metal versus polyethylene in hip arthroplasty: A randomized clinical trial. Clin Orthop Relat Res 2003;406:282-96.

3. Williams D, Royle M, Norton M. Metal-on-metal hip resurfacing: The effect of cup position and component size on range of motion to impingement. J Arthroplasty 2009;24:144-51.

4. Johnson AJ, Zywiel MG, Hooper H, Mont MA. Narrowed indications improve outcomes for hip resurfacing arthroplasty. Bull NYU Hosp Jt Dis 2011;69 Suppl 1:S27-9.

5. Bedigrew KM, Ruh EL, Zhang Q, Clohisy JC, Barrack RL, Nunley RM. 2011 Marshall Urist Young Investigator Award:
When to release patients to high-impact activities after hip resurfacing. Clin Orthop Relat Res 2012;470:299-306.

6. Bolland BJ, Culliford DJ, Langton DJ, Millington JP, Arden NK, Latham JM. High failure rates with a large-diameter hybrid metal-on-metal total hip replacement: Clinical, radiological and retrieval analysis. J Bone Joint Surg Br 2011;93:608-15.

7. Langton DJ, Jameson SS, Joyce TJ, Gandhi JN, Sidaginamale R, Mereddy $\mathrm{P}$, et al. Accelerating failure rate of the ASR total hip replacement. J Bone Joint Surg Br 2011;93:1011-6.

8. Langton DJ, Jameson SS, Joyce TJ, Hallab NJ, Natu S, Nargol AV. Early failure of metal-on-metal bearings in hip resurfacing and large-diameter total hip replacement: A consequence of excess wear. J Bone Joint Surg Br 2010;92:38-46.

9. Smith AJ, Dieppe P, Howard PW, Blom AW; National Joint Registry for England and Wales. Failure rates of metal-on-metal hip resurfacings: Analysis of data from the National Joint Registry for England and Wales. Lancet 2012;380:1759-66.

10. Corten K, MacDonald SJ. Hip resurfacing data from national joint registries: What do they tell us? What do they not tell us? Clin Orthop Relat Res 2010;468:351-7.

11. Smith AJ, Dieppe P, Vernon K, Porter M, Blom AW; National Joint Registry of England and Wales. Failure rates of stemmed metal-on-metal hip replacements: Analysis of data from the National Joint Registry of England and Wales. Lancet 2012;379:1199-204.

12. Kwon YM, Glyn-Jones S, Simpson DJ, Kamali A, McLardy-Smith P, Gill HS, et al. Analysis of wear of retrieved metal-on-metal hip resurfacing implants revised due to pseudotumours. J Bone Joint Surg Br 2010;92:356-61.

13. Pandit H, Glyn-Jones S, McLardy-Smith $\mathrm{P}$, Gundle $\mathrm{R}$, Whitwell D, Gibbons CL, et al. Pseudotumours associated with metal-on-metal hip resurfacings. J Bone Joint Surg $\mathrm{Br}$ 2008;90:847-51.

14. Topolovec M, Cör A, Milošev I. Metal-on-metal vs. metal-on-polyethylene total hip arthroplasty tribological evaluation of retrieved components and periprosthetic tissue. J Mech Behav Biomed Mater 2014;34:243-52.

15. Munro JT, Masri BA, Duncan CP, Garbuz DS. High complication rate after revision of large-head metal-on-metal total hip arthroplasty. Clin Orthop Relat Res 2014;472:523-8.

16. Grammatopoulos G, Pandit H, Kwon YM, Gundle R, McLardy-Smith P, Beard DJ, et al. Hip resurfacings revised for inflammatory pseudotumour have a poor outcome. J Bone Joint Surg Br 2009;91:1019-24.

17. Coulter G, Young DA, Dalziel RE, Shimmin AJ. Birmingham hip resurfacing at a mean of ten years: Results from an independent centre. J Bone Joint Surg Br 2012;94:315-21.

18. Matharu GS, McBryde CW, Pynsent WB, Pynsent PB, Treacy RB. The outcome of the Birmingham Hip Resurfacing in patients aged $<50$ years up to 14 years post-operatively. Bone Joint J 2013;95-B: 1172-7.

19. Murray DW, Grammatopoulos G, Pandit H, Gundle R, Gill HS, McLardy-Smith P. The ten-year survival of the Birmingham hip resurfacing: An independent series. J Bone Joint Surg $\mathrm{Br}$ 2012;94:1180-6.

20. Bozic KJ, Kurtz S, Lau E, Ong K, Chiu V, Vail TP, et al. The epidemiology of bearing surface usage in total hip arthroplasty in the United States. J Bone Joint Surg Am 2009;91:1614-20.

21. Metal-on-Metal Hip Implants - Information for Orthopaedic Surgeons. Available from: http://www.fda.gov/MedicalDevices/ ProductsandMedicalProcedures/ImplantsandProsthetics/ MetalonMetalHipImplants/ucm241667.htm. [Last accessed on 2017 Apr 20]. 
22. Metal-on-Metal (MoM) Hip Replacements - Updated Advice with Patient Follow ups Medical Safety Alert - GOV. UK. Available from: http://www.gov.uk/drug-device-alerts/medical -device-alert-metal-on-metal-mom-hip-replacements-updatedadvice-with-patient-follow-ups. [Last accessed on 2017 Apr 20].

23. Günther KP, Schmitt J, Campbell P, Delaunay CP, Drexler H, Ettema HB, et al. Consensus statement "Current evidence on the management of metal-on-metal bearings" April 16, 2012. Hip Int 2013;23:2-5.

24. Final Opinion on Metal-on-Metal Joint Replacements - Public Health - European Commission. Public Health. Available from: http://www.health/scientific_committees/consultations/public consultations/scenihr_consultation_20_en. [Last accessed on 2017 Apr 22].

25. Therapeutic Goods Administration (TGA). Available from: http:// www.tga.gov.au/search/node. [Last accessed on 2017 Apr 20].

26. Metal-on-Metal Hip Implants - Information for Orthopaedic Surgeons Regarding Patient Management Following Surgery - For Health Professionals. Available from: http:// www.healthycanadians.gc.ca/recall-alert-rappel-avis/ hc-sc/2012/15835a-eng.php. [Last accessed on 2017 Apr 20].

27. Haughom BD, Erickson BJ, Hellman MD, Jacobs JJ. Do complication rates differ by gender after metal-on-metal hip resurfacing arthroplasty? A systematic review. Clin Orthop Relat Res 2015;473:2521-9.

28. Bayley N, Khan H, Grosso P, Hupel T, Stevens D, Snider M, et al. What are the predictors and prevalence of pseudotumor and elevated metal ions after large-diameter metal-on-metal THA? Clin Orthop Relat Res 2015;473:477-84.

29. Mathiesen EB, Lindgren JU, Blomgren GG, Reinholt FP. Corrosion of modular hip prostheses. J Bone Joint Surg $\mathrm{Br}$ 1991;73:569-75.

30. Ebramzadeh E, Campbell P, Tan TL, Nelson SD, Sangiorgio SN. Can wear explain the histological variation around metal-on-metal total hips? Clin Orthop Relat Res 2015;473:487-94.

31. Pattyn CA, Lauwagie SN, Verdonk RC. Whole blood metal ion concentrations in correlation with activity level in three different metal-on-metal bearings. J Arthroplasty 2011;26:58-64.

32. Fehring TK, Odum S, Sproul R, Weathersbee J. High frequency of adverse local tissue reactions in asymptomatic patients with metal-on-metal THA. Clin Orthop Relat Res 2014;472:517-22.

33. Hart AJ, Satchithananda K, Liddle AD, Sabah SA, McRobbie D, Henckel J, et al. Pseudotumors in association with well-functioning metal-on-metal hip prostheses: A case-control study using three-dimensional computed tomography and magnetic resonance imaging. J Bone Joint Surg Am 2012;94:317-25.

34. Wynn-Jones $\mathrm{H}$, Macnair $\mathrm{R}$, Wimhurst J, Chirodian $\mathrm{N}$, Derbyshire B, Toms A, et al. Silent soft tissue pathology is common with a modern metal-on-metal hip arthroplasty. Acta Orthop 2011;82:301-7.

35. Van Der Straeten C, Grammatopoulos G, Gill HS, Calistri A, Campbell P, De Smet KA. The 2012 Otto Aufranc Award: The interpretation of metal ion levels in unilateral and bilateral hip resurfacing. Clin Orthop Relat Res 2013;471:377-85.

36. Langton DJ, Sidaginamale RP, Joyce TJ, Natu S, Blain P, Jefferson $\mathrm{RD}$, et al. The clinical implications of elevated blood metal ion concentrations in asymptomatic patients with MoM hip resurfacings: A cohort study. BMJ Open 2013;3. pii: E001541.

37. Hart AJ, Sabah SA, Sampson B, Skinner JA, Powell JJ, Palla L, et al. Surveillance of patients with metal-on-metal hip resurfacing and total hip prostheses: A prospective cohort study to investigate the relationship between blood metal ion levels and implant failure. J Bone Joint Surg Am 2014;96:1091-9.
38. Reito A, Lainiala O, Nieminen J, Eskelinen A. Repeated metal ion measurement in patients with bilateral metal on metal (ASR ${ }^{\mathrm{TM}}$ ) hip replacements. Orthop Traumatol Surg Res 2016;102:167-73.

39. Lombardi AV Jr., Barrack RL, Berend KR, Cuckler JM, Jacobs JJ, Mont MA, et al. The Hip Society: Algorithmic approach to diagnosis and management of metal-on-metal arthroplasty. J Bone Joint Surg Br 2012;94 11 Suppl A:14-8.

40. Ebreo D, Bell PJ, Arshad H, Donell ST, Toms A, Nolan JF. Serial magnetic resonance imaging of metal-on-metal total hip replacements. Follow-up of a cohort of $28 \mathrm{~mm}$ Ultima TPS THRs. Bone Joint J 2013;95-B: 1035-9.

41. van der Weegen W, Brakel K, Horn RJ, Hoekstra HJ, Sijbesma T, Pilot $\mathrm{P}$, et al. Asymptomatic pseudotumours after metal-on-metal hip resurfacing show little change within one year. Bone Joint $\mathrm{J}$ 2013;95-B: 1626-31.

42. Lainiala O, Elo P, Reito A, Pajamäki J, Puolakka T, Eskelinen A. Comparison of extracapsular pseudotumors seen in magnetic resonance imaging and in revision surgery of 167 failed metal-on-metal hip replacements. Acta Orthop 2014;85:474-9.

43. Amanatullah DF, Sucher MG, Bonadurer GF $3^{\text {rd }}$, Pereira GC, Taunton MJ. Metal in total hip arthroplasty: Wear particles, biology, and diagnosis. Orthopedics 2016;39:371-9.

44. Almousa SA, Greidanus NV, Masri BA, Duncan CP, Garbuz DS. The natural history of inflammatory pseudotumors in asymptomatic patients after metal-on-metal hip arthroplasty. Clin Orthop Relat Res 2013;471:3814-21.

45. De Pasquale D, Stea S, Squarzoni S, Bordini B, Amabile M, Catalani $\mathrm{S}$, et al. Metal-on-metal hip prostheses: Correlation between debris in the synovial fluid and levels of cobalt and chromium ions in the bloodstream. Int Orthop 2014;38:469-75.

46. Engh CA, MacDonald SJ, Sritulanondha S, Korczak A, Naudie D, Engh C. Metal ion levels after metal-on-metal total hip arthroplasty: A five-year, prospective randomized trial. J Bone Joint Surg Am 2014;96:448-55.

47. Sidaginamale RP, Joyce TJ, Lord JK, Jefferson R, Blain PG, Nargol AV, et al. Blood metal ion testing is an effectivescreening tool to identify poorly performing metal-on-metal bearingsurfaces. Bone Joint Res 2013;2:84-95.

48. Kwon YM, Lombardi AV, Jacobs JJ, Fehring TK, Lewis CG, Cabanela ME. Risk stratification algorithm for management of patients with metal-on-metal hip arthroplasty: Consensus Statement of the American Association of Hip and Knee Surgeons, the American Academy of Orthopaedic Surgeons, and the Hip Society. J Bone Joint Surg Am 2014;96:e4.

49. Hothi HS, Berber R, Panagiotopoulos AC, Whittaker RK, Rhead C, Skinner JA, et al. Clinical significance of corrosion of cemented femoral stems in metal-on-metal hips: A retrieval study. Int Orthop 2016;40:2247-54.

50. Vendittoli PA, Mottard S, Roy AG, Dupont C, Lavigne M. Chromium and cobalt ion release following the Durom high carbon content, forged metal-on-metal surface replacement of the hip. J Bone Joint Surg Br 2007;89:441-8.

51. Hart AJ, Sabah SA, Bandi AS, Maggiore P, Tarassoli P, Sampson B, et al. Sensitivity and specificity of blood cobalt and chromium metal ions for predicting failure of metal-on-metal hip replacement. J Bone Joint Surg $\mathrm{Br}$ 2011;93:1308-13.

52. Reito A, Moilanen T, Puolakka T, Pajamäki J, Eskelinen A. Repeated metal ion measurements in patients with high risk metal-on-metal hip replacement. Int Orthop 2014;38:1353-61.

53. Langton DJ, Joyce TJ, Jameson SS, Lord J, Van Orsouw M, Holland JP, et al. Adverse reaction to metal debris following hip 
resurfacing: The influence of component type, orientation and volumetric wear. J Bone Joint Surg Br 2011;93:164-71.

54. Silverman EJ, Ashley B, Sheth NP. Metal-on-metal total hip arthroplasty: Is there still a role in 2016? Curr Rev Musculoskelet Med 2016;9:93-6.

55. Liow MH, Kwon YM. Metal-on-metal total hip arthroplasty: Risk factors for pseudotumours and clinical systematic evaluation. Int Orthop 2017;41:885-92.

56. Liddle AD, Satchithananda K, Henckel J, Sabah SA, Vipulendran KV, Lewis A, et al. Revision of metal-on-metal hip arthroplasty in a tertiary center: A prospective study of 39 hips with between 1 and 4 years of follow-up. Acta Orthop 2013;84:237-45.

57. De Smet KA, Van Der Straeten C, Van Orsouw M, Doubi R, Backers K, Grammatopoulos G. Revisions of metal-on-metal hip resurfacing: Lessons learned and improved outcome. Orthop Clin North Am 2011;42:259-69, ix.

58. Matharu GS, Pynsent PB, Dunlop DJ. Revision of metal-on-metal hip replacements and resurfacings for adverse reaction to metal debris: A systematic review of outcomes. Hip Int 2014;24:311-20. 